\title{
Dynamics of Contention in the Gig Economy: Rage Against the Platform, Customer, or
}

\section{State?}

Accepted to New Technology, Work \& Employment

For Special Issue: The 'new' social relations of digital technology and the future of work

\section{Authors:}

Alex J. WOOD ${ }^{1}$

Nicholas MARTINDALE ${ }^{2}$

Vili LEHDONVIRTA ${ }^{3}$

${ }^{1}$ University of Bristol

${ }^{2}$ Nuffield College, University of Oxford.

${ }^{3}$ Oxford Internet Institute, University of Oxford

\section{Acknowledgments}

The authors would like to acknowledge the European Centre for the Development of Vocational Training for the generous funding which made the survey possible as well as all those involved in its design and collection Anoush Margaryan, Julian Albert, Susanne Klausing, Laura Larke, Huw Davies, Laura Pinkerton, Siân Brooke, Otto Kässi and Gretta Corporaal.

\footnotetext{
Abstract

Protest in the gig economy has taken many forms and targets (platforms, customers, and state officials). However, researchers are yet to adequately account for this diversity. We use a European survey of Upwork and PeoplePerHour platform workers in the remote gig economy to investigate worker orientation towards different forms of protest. Results reveal that worker anger, dependence, and digital communication shape contention in the remote gig
} 
economy. Support for collective organisation is associated not only with anger at platforms but also workers' dependence on the platform and communication with other workers. Whereas individual action against clients is associated only with anger and communication but not communication and support for state regulation is associated only with anger but not dependence or communication. We conclude that despite the novelty of these emergent social relations, the relational approach entailed by Mobilisation Theory can aid explanation of contention in the gig economy by shedding light on the dynamic process by which solidarity and dependence alter the perceived costs and benefits of particular remedies to injustice.

\section{Key words}

Gig economy, online freelancing, platform work, protest, mobilisation, resistance, state regulation

\section{Introduction}

Protest and contention in the gig economy are increasingly common. A recent index of media reports finds that there have been 330 incidences of platform worker protest globally since January 2015 (Joyce et al., 2020). The gig economy consists of workers selling labour via platforms both locally (thus requiring the worker to be physically proximate to the customer) and remotely (enabling the service to be provided without physical proximity to the customer) (Huws et al., 2016; Wood et al., 2018; 2019a). The local gig economy consists of work such as ride hailing and delivery (e.g., Uber and Deliveroo) while the remote gig economy consists of tasks that can be delivered over the Internet, such as data entry, graphic design, and content writing 
(e.g. Upwork, Fiverr, PeoplePerHour, Freelancer.com and Amazon's Mechanical Turk). Protest and contentious actions in both the local and remote gig economy have taken many forms (strikes, demonstrations, legal action etc.) and have aimed at influencing a variety of targets (online platforms, state officials, customers). While the field of industrial relations has traditionally focused on the relations between workers, employers, and the state (Dunlop, 1958), social relations in platform work are more complex. Rather than acting as traditional employers, platforms operate as multi-sided markets matching customers who request goods and services with workers who provide them (Evans, 2003; Lehdonvirta et al., 2019; Wood and Lehdonvirta, 2021a). Researchers have therefore documented protests focused on the relations between workers' and customers (Irani and Silberman, 2013; Lehdonvirta, 2016, Wood et al., 2018); workers and platforms (Cant, 2019; Lehdonvirta, 2016; Tassinari and Maccarrone, 2020; Wood and Lehdonvirta, 2021a); and workers and the state (Aslam and Woodcock, 2020; Johnston and Land-Kazlauskas, 2019). Explanations of protest in the gig economy must therefore account for the differing social relations that exist between workers, customers, platforms, and the state.

Existing research has sought to make sense of this social complexity and its relationship with platform worker protest primarily through the qualitative analysis of instances of collective mobilisation. This research has succeeded in highlighting a range of factors associated with the propensity to protest, including anger generated by antagonisms inherent to gig work, the dependence of workers on their platforms, and the presence of collective solidarity among workers, often mediated by digital communication networks. However, researchers are yet to synthesise this knowledge to understand why, at different times and in different places, platform worker protest takes particular forms and variously targets platforms, customers, and the state. Moreover, existing studies have focused on cases where collective mobilisation has occurred, which is problematic for two reasons. First, cases 
of smaller scale protest and individual resistance, which tend to take customers and clients as their target, have been neglected. Workers in the remote gig economy have been found to take action against clients by leaving negative feedback for clients (Anwar and Graham, 2020a) and to download plugins which enable them to rate their clients even when the platform does not enable them to do so (Irani and Silberman, 2013). Workers in this sector have also been found to enforce price norms so that other workers do not accept work from low paying clients (Wood et al., 2018) and to publicly shame bad clients (Anwar and Graham, 2020a; Wood et al., 2018), as well as withholding work (Anwar and Graham, 2020a) and threatening to end contracts with bad clients (Wood and Lehdonvirta, 2021a). Wood et al. (2019a) also detail how remote gig workers find ways to circumvent client monitoring of their work through learning when screenshots of their desktop will be taken and using secondary monitors. In the local gig economy, research has highlighted how workers take action against customers, with Möhlmann and Zalmanson (2017) documenting how ride hail drivers cancel rides to avoid bad customers/ratings. Additionally, in the delivery sector Cant and Woodcock (2020) document riders protesting McDonalds regarding delivery waiting times. These examples of worker action against clients and customers are potentially important, as Thompson and Ackroyd (1999) highlight that workers may undertake acts of 'organisational misbehaviour' even in the absence of formal collective organisation and unions and, in fact, Atzeni (2016) argues that such worker self-activity can be a precursor to collective association.

Second, by focusing on instances of the successful realisation of collective action previous research has tended to sample on the dependent variable. That is, it has sought to explain cases of the successful realisation of the phenomenon under consideration while ignoring the much more common absence of collective protest in similar circumstances. Additionally, with some notable qualitative exceptions (e.g. Anwar and Graham, 2020a; Irani 
and Silberman, 2013; Lehdonvirta, 2016; Panteli et al., 2020; Wood et al., 2018; Wood and Lehdonvirta, 2021a) most research has focused on contention in the local gig economy. While there are many similarities in platform affordances and business practices across the local/remote divide (Gandini, 2019; Kellogg et al., 2020; Vallas and Schor, 2020), there are some significant differences (Howcroft and Bergvall-Kåreborn, 2019) which may influence the dynamics of contention. Wood et al. (2019a) provide a detailed qualitative account of the labour process entailed by 'macro' freelance type platform work in the remote gig economy and highlight how working conditions are shaped by platform's use of algorithmic control. In particular, this research highlights that workers frequently experience autonomy but also highly intense work during anti-social hours, while pay and precarity are polarised and dependent on an individuals' platform reputation. This article, therefore, makes an important contribution by investigating contention in this under studied sector of the remote gig economy. In the discussion we consider the degree to which our findings may be influenced by the specific nature of the remote gig economy and thus differ from the local gig economy.

In this article we investigate how the complex social relations of the gig economy influence workers' support for and engagement in different forms of protest. To do so, we focus not only on collective protest aimed at employers and the state, but also on less visible forms of individual protest directed at customers and clients. We analyse a survey of platform workers based in Europe who provide remote digital services on the platforms Upwork and PeoplePerHour. A survey approach enables the analyses to control for the simultaneous influence of individual and contextual factors on support for protest, while also reaching a broader spectrum of workers (including those not protesting) than previous studies. This research also constitutes the first quantitative investigation of protest in the remote gig economy and thus provides an important counterpoint to research into the local gig economy - a point we return to in the discussion. 
Our findings reveal that different forms of protest have different determinants. We find support for collective organisation (i.e. unions) is significantly associated with all three of the factors highlighted in the existing literature: worker anger at the antagonisms inherent to gig work, dependence on platforms, and frequent digital communication with other platform workers which generates solidarity. However, engagement in individual forms of protest against clients is significantly associated with worker anger and communication, but not with dependence. Support for greater state regulation of platforms is associated with worker anger, but not with dependence or communication. We argue that the differing level of perceived risk associated with each form of contention explains this variation. Moreover, we argue that the relational approach of Kelly's (1998) Mobilisation Theory is well placed to explain this diversity. In this way, this article makes novel empirical and theoretical contributions to our understanding of the relationship between the social relations of the gig economy and different forms of platform worker protest.

\section{Social Relations and Protest in the Gig Economy}

Extant research has highlighted the existence of protest across the diverse industries and platforms that make up the gig economy, including participation in strikes, demonstrations, and legal action. An overview of existing scholarship on gig worker protest in Table 1 highlights the diversity of targets and forms of protest. Protests have been documented in which the targets of workers' demands have variously been: customers (Irani and Silberman, 2013; Lehdonvirta, 2016, Wood et al., 2018); platforms (Cant, 2019; Cini and Goldmann, 2020; Lei, 2021; Lehdonvirta, 2016; Tassinari and Maccarrone, 2020; Wood and Lehdonvirta, 2021a); and the state (Aslam and Woodcock, 2020; Johnston and Land- 
Kazlauskas, 2019). Workers have participated in strikes, demonstrations, and legal actions; sought to influence price norms; and utilised and contributed to client-rating software.

Table 1: Existing Research on Protest in the Gig Economy

\begin{tabular}{|c|c|c|c|c|}
\hline $\begin{array}{l}\text { Target of } \\
\text { Protest }\end{array}$ & Platform & Industry & Action & Citation \\
\hline \multirow[t]{8}{*}{ Customer } & MTurk & Digital & Client rating plugin & $\begin{array}{l}\text { Irani \& Silberman } \\
(2013)\end{array}$ \\
\hline & $\begin{array}{l}\text { Freelance } \\
\text { Platform }\end{array}$ & Digital & Price norms & Wood et al. (2018) \\
\hline & $\begin{array}{l}\text { Freelance } \\
\text { platform }\end{array}$ & Digital & $\begin{array}{l}\text { Publicly shame bad } \\
\text { clients }\end{array}$ & $\begin{array}{l}\text { Anwar and Graham, } \\
(2020 \mathrm{a}) \text {; Wood et al., } \\
(2018)\end{array}$ \\
\hline & $\begin{array}{l}\text { Freelance } \\
\text { platform }\end{array}$ & Digital & $\begin{array}{l}\text { Threats to end } \\
\text { contract }\end{array}$ & $\begin{array}{l}\text { Wood and } \\
\text { Lehdonvirta (2021a) }\end{array}$ \\
\hline & $\begin{array}{l}\text { Freelance } \\
\text { platform }\end{array}$ & Digital & $\begin{array}{l}\text { Withhold work from } \\
\text { clients }\end{array}$ & $\begin{array}{l}\text { Anwar and Graham, } \\
\text { (2020a) }\end{array}$ \\
\hline & $\begin{array}{l}\text { Freelance } \\
\text { platform }\end{array}$ & Digital & $\begin{array}{l}\text { Circumvent client } \\
\text { monitoring of work }\end{array}$ & $\begin{array}{l}\text { Anwar and Graham, } \\
(2020 \mathrm{a}) \text {; Wood et al., } \\
(2019 \mathrm{a})\end{array}$ \\
\hline & Uber & Driving & $\begin{array}{l}\text { Cancelling rides to } \\
\text { avoid bad } \\
\text { customers/ratings. }\end{array}$ & $\begin{array}{l}\text { Möhlmann and } \\
\text { Zalmanson (2017) }\end{array}$ \\
\hline & UberEats & Delivery & $\begin{array}{l}\text { Protests outside } \\
\text { restaurants for } \\
\text { reduced waiting times }\end{array}$ & $\begin{array}{l}\text { Cant \& Woodcock } \\
(2020)\end{array}$ \\
\hline \multirow[t]{9}{*}{ Platform } & MTurk & Digital & $\begin{array}{l}\text { Petition and email } \\
\text { campaign }\end{array}$ & Lehdonvirta (2016) \\
\hline & $\begin{array}{l}\text { Freelance } \\
\text { Platform } \\
\end{array}$ & Digital & $\begin{array}{l}\text { Petition and forum } \\
\text { campaign }\end{array}$ & $\begin{array}{l}\text { Wood \& Lehdonvirta } \\
(2019)\end{array}$ \\
\hline & Deliveroo & Delivery & $\begin{array}{l}\text { Strikes and } \\
\text { demonstrations }\end{array}$ & $\begin{array}{l}\text { Cant (2019); } \\
\text { Tassinari and } \\
\text { Maccarrone (2020); } \\
\text { Cini and Goldmann } \\
(2020)\end{array}$ \\
\hline & Foodora & Delivery & $\begin{array}{l}\text { Strikes and } \\
\text { demonstrations }\end{array}$ & $\begin{array}{l}\text { Tassinari and } \\
\text { Maccarrone (2020) }\end{array}$ \\
\hline & UberEats & Delivery & $\begin{array}{l}\text { Strikes and } \\
\text { demonstrations }\end{array}$ & $\begin{array}{l}\text { Cant \& Woodcock } \\
(2020)\end{array}$ \\
\hline & Uber & Driving & $\begin{array}{l}\text { Strikes and } \\
\text { demonstrations }\end{array}$ & $\begin{array}{l}\text { Aslam \& Woodcook } \\
(2019)\end{array}$ \\
\hline & Meituan & Delivery & $\begin{array}{l}\text { Strikes and } \\
\text { demonstrations }\end{array}$ & Lei (2021) \\
\hline & Ele.me & Delivery & $\begin{array}{l}\text { Strikes and } \\
\text { demonstrations }\end{array}$ & Lei (2021) \\
\hline & Didi & Driving & App Bots & Chen (2018) \\
\hline
\end{tabular}




\begin{tabular}{|l|l|l|l|l|}
\hline State & Uber & Driving & $\begin{array}{l}\text { Demonstrations; } \\
\text { legal action; legal } \\
\text { enactment }\end{array}$ & $\begin{array}{l}\text { Aslam \& Woodcook } \\
\text { (2019); Johnston and } \\
\text { Land-Kazlauskas } \\
(2019)\end{array}$ \\
\hline & Crowdflower & Digital & Legal action & Lehdonvirta (2016) \\
\hline
\end{tabular}

Across the existing scholarship, there appears to be little evidence of any industrybased pattern in the forms or targets of protest undertaken by gig workers. An analysis of media reports undertaken by Joyce et al. (2020) similarly finds substantial variation in the patterning of the protest actions undertaken by platform workers in the local gig economy. This raises the question of how to account for the diversity of protest in the gig economy.

Clues as to why these workers engage in protest can be gleaned from extant qualitative studies of platform worker protest. Tassinari and Maccarrone's (2020) study of strikes and demonstrations by food delivery workers in the UK and Italy highlights how protests against platforms emerged spontaneously as a result of antagonism inherent to the labour process. This antagonism manifested as anger at low pay, changes to the payment method, uncertainty over earnings and working hours, absence of sick pay, health and safety, non-transparent performance management, shift allocation, and deactivation. Likewise, Lei (2021) finds that the manner in which platforms organise work in the Chinese food delivery sector generates grievances that can spark collective action. In the remote gig economy, Wood and Lehdonvirta (2021a) detail how antagonism manifests as anger towards platform fees, low pay rates, and lack of voice channels and can lead to collective protest and support for unions when workers are unable to easily exit their platforms due to the dependency resulting from platform gate keeping, network effects and data lock-in. This claim is supported by the earlier finding that workers who are more dependent on a platform are more likely to support collaborative efforts to raise their wages (Wood et. al., 2018). Similarly, Joyce (2020) argues that platform dependence fuels protest by creating an unstable 'cashnexus' between workers and their platforms. Chinese food delivery workers who are 
dependent on the work have also been found to be more likely to engage in collective action (Lei, 2021). In contrast, the lack of attachment to platform work among food delivery workers in Australia has been found to reduce contention (Barratt et al., 2020). These findings are in line with dependency and attachment having been found to shape other work outcomes, such as dissatisfaction, autonomy, hourly wages, and precarity (Dunn, 2020; Goods et al., 2019; Josserand and Kaine, 2019; Lei, 2021; Ravenelle, 2019; Schor et al., 2020). Therefore, previous research into platform work suggests that anger combined with dependence on platforms are two important factors that may explain contention in the gig economy. These findings can be related to Kelly's (1998) 'Mobilisation Theory' synthesis of social movement research (principally, Tilly, 1978; McAdam,1988; and Snow et al., 1986). ${ }^{1}$ Kelly's approach highlights that workers may take different forms of protest action due to the varying intensity of anger and sense of injustice generated by antagonisms at work and because dependence on individual platforms alters the perceived cost/benefits of voice.

Additionally, Tassinari and Maccarrone (2020: 5) build on the work of Atzeni (2009; 2010) to highlight the importance of generation of 'collective feelings of reciprocity and responsibility'. Atzeni (2009; 2010), argues the labour process necessitates worker socialisation and this leads to the formation of embryonic solidarity between workers placed in a common situation of dependence. According to Atzeni (2009; 2010) this embryonic solidarity forms the basis for the active solidarity of undertaking collective action (see also: Tassinari and Maccarrone, 2020). The term solidarity relates to 'a communal sense of obligation to support collective action' (Heckscher and McCarthy, 2014: 629) and can be understood in terms of Putnam's (2001) discussion of social capital in which a sense of solidarity develops via bonding and bridging within and between groups with situational commonalities (Jarley, 2005; Morgan and Pulignano, 2019; Saundry et al. 2012). Wood $(2015 ; 2020)$ has demonstrated that inter-worker communication via digital technologies can 
lead to the development of a sense of 'networked solidarity' amongst spatially and temporally fragmented workers. In their study of Foodora and Deliveroo workers, Tassinari and Maccarrone's (2020) find that solidarity developed between gig workers as they provided each other with help and support while gathered at order waiting points and via digital networks and communities (see also: Cini and Goldmann, 2020). The importance of communication for solidarity is highlighted in other studies of collective action in the local gig economy. For instance, in ride hailing, Aslam and Woodcock (2019) and Maffie (2020) find that gig workers engage in digital communication in search of help and support for dealing with customers. Such embryonic solidarity has additionally been found to form the basis of protest against platforms and support for unions among ride hail and food delivery workers (Aslam and Woodcock, 2019; Cini and Goldmann, 2020; Cant, 2019; Cant and Woodcock; 2020; Maffie, 2020; Tassinari and Maccarrone, 2020). The importance of communication and the generation of solidarity for protest can, like anger and dependence, be related to Kelly's (1998) Mobilisation Theory which highlights the importance of a sense of collective interests existing for protest to take place. Kelly (1998: 37) argues that this entails the development of a shared perception of group membership and is influenced by worker interaction and the density of social networks. Individuals thus come to see group membership as a distinct social category which is defined in opposition to an out-group who have different interests and values. Group identification is particularly important as it is argued to strengthen and amplify outrage at perceived injustices through a process of reinforcement and legitimisation (Kelly, 1998).

Existing research has therefore highlighted three important aspects of gig economy social relations that lead both to the emergence of protest against platforms and to support for unions: (1) anger generated by poor working conditions; (2) experiences of dependence on particular platforms; (3) emergence of solidarity between workers on the same platform. 
However, due to a lack quantitative data, researchers have not yet been able to adequately explain why these factors lead to different forms of protest by platform workers at different times, including less well studied instances of individual actions against customers or claims made on the state. Additionally, the role of embryonic solidarity and communication in facilitating support for unions has only been explored quantitively in the local gig economy, by Maffie (2020) and Newlands et al. (2018).

Methodologically, existing research has largely relied on interviews with workers involved in singular instances of protest or cycles of contention. This makes it difficult to draw broader conclusions about the determinants of protest in other settings, why some workers fail to protest when others do, or why the targets and forms of protest have been so variable. Appropriate survey data can contribute towards our understanding of protest in the gig economy by reaching a broader range of workers, and by assessing the simultaneous influence of individual and contextual factors, which influence both support for protest and individual acts of resistance. In the rest of this article, we seek to address the limitations of previous research on gig economy protest by using novel survey data to investigate the role of antagonisms, dependence, and solidarity in explaining gig worker support for different forms of protest and contention.

\section{Data and Methods}

Data for the analyses comes from a recent survey of freelancers $(\mathrm{N}=430)$ working on two prominent online labour platforms for remote digital services (Upwork and PeoplePerHour). The services include data entry, graphic design, digital marketing, translation, transcription, and programming, amongst others. The survey was commissioned by the European Centre for the Development of Vocational Training of the European Union to investigate online 
freelancers working in six European countries: Finland ( $\mathrm{N}=76)$, Germany (63), Italy (70), Romania (78), Spain (69), and the UK (74). The survey included questions on workers' experiences of and attitudes towards online platform work. The survey targeted workers aged 18 and over, with experience on the target platform, and located in one of the six target countries. Workers belonging to this population were identified using platform search functions and invited to complete the survey until equal quotas for sex and country were approximately filled. Workers were picked randomly from each search results page as opposed to systematically following the results, to mitigate algorithmic bias. A response rate of $20 \%$ for successfully completed questionnaires was achieved. Survey respondents were paid USD 9.50, EUR 8.50 or GBP 7-7.50 depending on their preferred means (in-platform payment or Amazon gift card), exchange rates, and platform fees.

Despite best efforts, the sampling procedure does impose limitations on the generalisability of the findings. In particular, there is likely self-selection into the sample by preference for answering surveys, which could be due to differences in opportunity costs. However, our respondents are similar in age and educational characteristics to the respondents of a large-scale survey conducted for the European Union's COLLEEM project (Pesole et al., 2018). Respondents are young (Figure 1) and highly educated (Figure 2): more than three quarters are under 40 , and $68 \%$ have completed at least an undergraduate degree. This suggests that at least in demographic characteristics the sample is reflective of the broader gig worker population in Europe. 
Figure 1: Sex and Age Group of Respondents

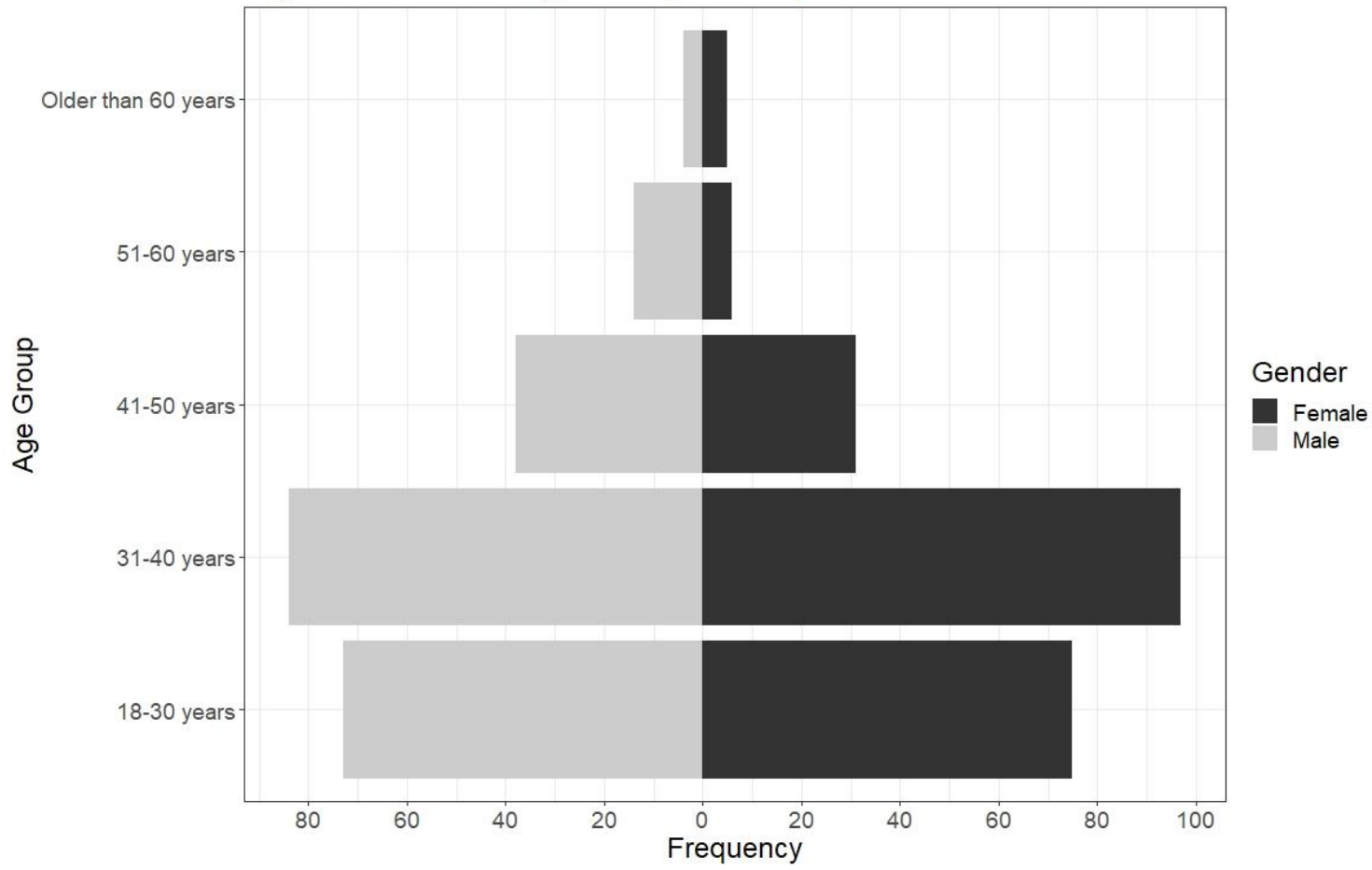

Figure 2: What is the highest level of education you have completed?

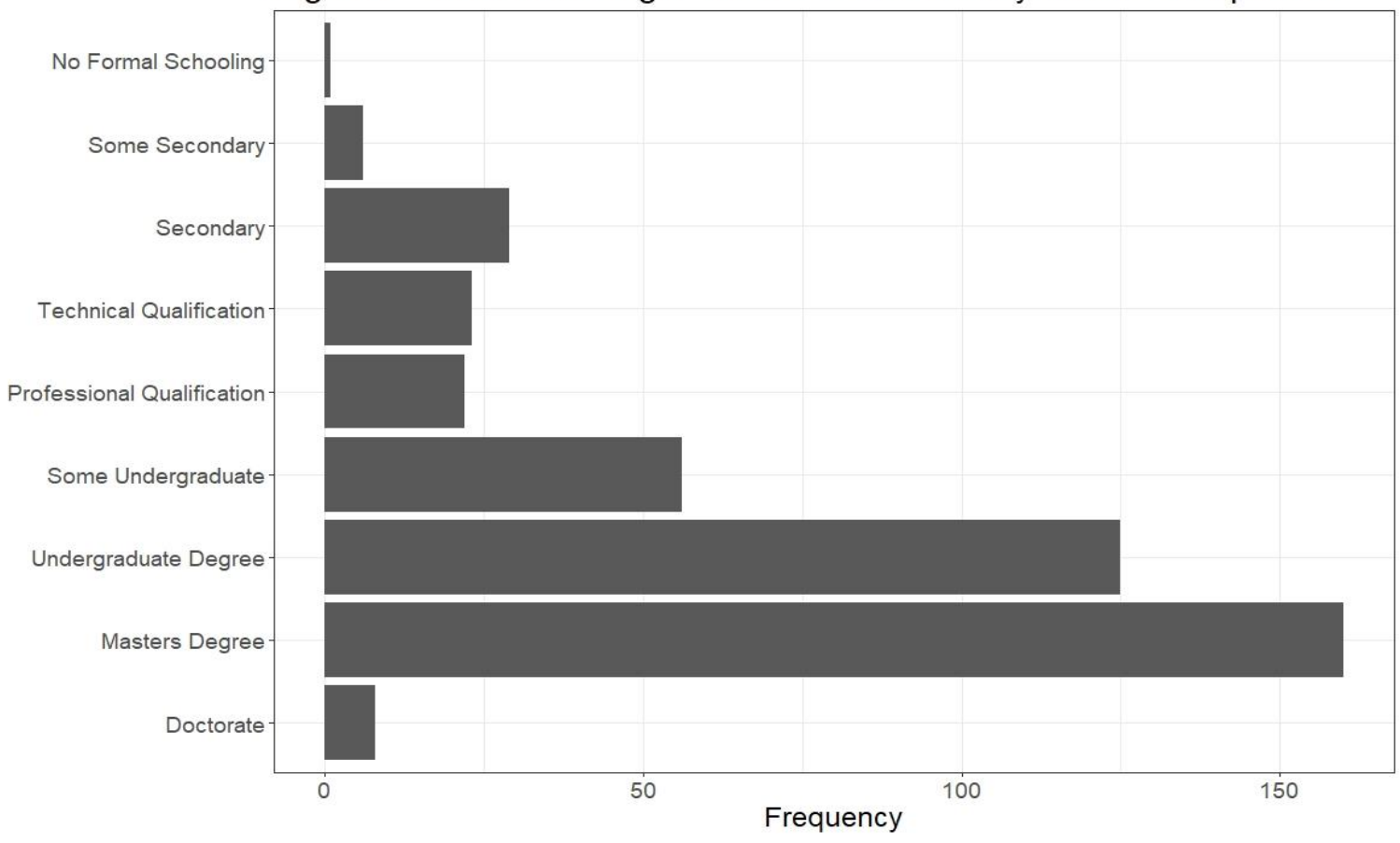


To investigate the extent to which respondents engage in or support different forms of protest, we constructed three composite dependent variables. The variables measure the extent to which respondents (1) have taken action against their clients (“Client Action”), (2) support collective organisation (“Collective Organisation”), and (3) support greater application of state regulation on platforms ("State Regulation"). Each of these composite dependent variables was constructed by summing relevant five-category Likert-scale items from the survey. ${ }^{2}$ Client Action comprises three items measuring the extent to which workers' treatment by clients led them to (i) threaten to end a contract with a client, (ii) end a contract, and (iii) refuse to continue working for a client $(\alpha=0.72)$. Collective Organisation likewise comprises three items: (i) wanting to improve wages collaboratively, (ii) interest in joining, and (iii) interest in forming a freelancer union $(\alpha=0.83)$. State Regulation comprises two items: whether (i) national minimum wages should be paid by platforms and whether (ii) states should do more to regulate platforms $(\rho=0.38)$. Greater detail on the distributions of the underlying factors in these composite dependent variables (and the independent variables described below) can be found in the first stage of the analysis in the next section of this article.

To investigate the determinants of support for different forms of protest, we also constructed three composite independent variables. These variables measure aspects of the social relations of gig work, which previous research has argued are associated with support for protest. The variables measure the extent of workers' (1) anger at their working conditions (“Anger"), their (2) dependence on the platform for work ("Dependence"), and (3) how frequently they communicated with other workers (“Communication”).

The Anger variable measures how frustrated workers feel about working on the platform by summing nine relevant five-category Likert-scale items that capture attitudes towards pay from clients (too low, lower than deserved, late), fees charged by the platform 
(too high), and experiences of working for clients and platforms (treated unfairly, not supported, exploitative, too much competition from abroad, platforms have too much power) $(\alpha=0.74)$. These items reflect the antagonism built into the labour process of platform work (Wood and Lehdonvirta, 2021a).

The Dependence variable measures the extent to which workers are unable to act on their grievances or exert power over their clients or platforms. The variable comprises nine relevant items: unable to replace clients, unable to criticise clients, unable switch platform without loss of income, unable to redress unfair treatment, feeling replaceable, feeling afraid to ask for better conditions, feeling helpless, having to work too many hours, fearing platform fee increases, and fearing the effect of unfair feedback on income $(\alpha=0.72){ }^{3}$

The Communication variable sums three relevant seven-category items which measure the frequency of communicating with other workers via online forums, social media (including text messaging and email), and face-to-face $(\alpha=0.66)$. As indicated in the statistical tests in parentheses above (Cronbach's alpha, $\alpha$, and Pearson correlation coefficient, $\rho$ ), the resulting item sets generally do have very good internal correlation, with the possible exception of the State Regulation measure $(\rho=0.38)$. For exploratory research, such as this, we do consider a $\rho$ in excess of 0.3 acceptable, however.

\section{Findings}

Anger, dependence, and communication among remote platform workers

First, we examine the distribution of responses for the independent variables. Our findings suggest that, although our respondents generally feel fairly treated, there is a high level of discontent related to the material rewards of platform work. Figure 3, which plots the distributions of underlying items in Anger, reveals that among our survey respondents at least $75 \%$ of workers believe that the fees platforms charge are too high and that the pay which 
workers receive is too low. At least $50 \%$ believe that their pay is less than they deserve, and that foreign competition should be limited. Sizable minorities believe that platforms benefit shareholders at the expense of workers (42\%) and that platforms have too much power $(24 \%)$.

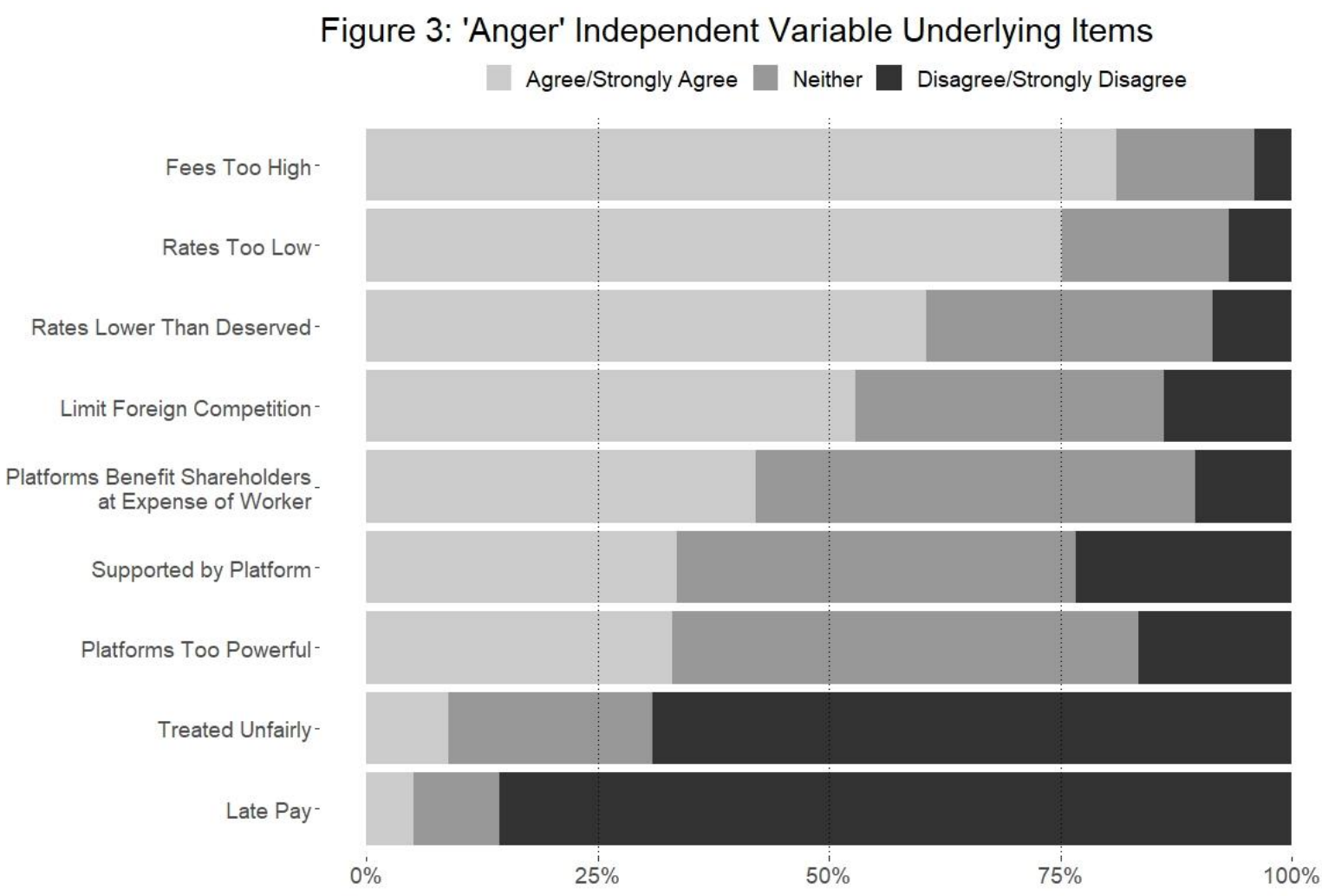

Figure 4, which plots the distributions of the underlying items in Dependence, reveals that many workers experience dependence on the platform on which they work. For instance, more than half could not switch the platform on which they work without substantial loss of income. More than $75 \%$ feared that their platform would increase the fees they are charging. A significant minority of workers indicated that they had a weak bargaining position relative to clients, suggesting that they are likely to also be in a position of dependence with regards to their clients. For instance, more than $25 \%$ of workers indicated that they are afraid to demand better work terms and hourly rates, that they feel helpless when unfairly treated by clients, that they are unable to easily replace clients, and that they feel replaceable. Additionally, $62 \%$ of workers feared the effect of unfair feedback on their future income. 
Figure 4: 'Dependence' Independent Variable Underlying Items Agree/Strongly Agree Neither $\square$ Disagree/Strongly Disagree

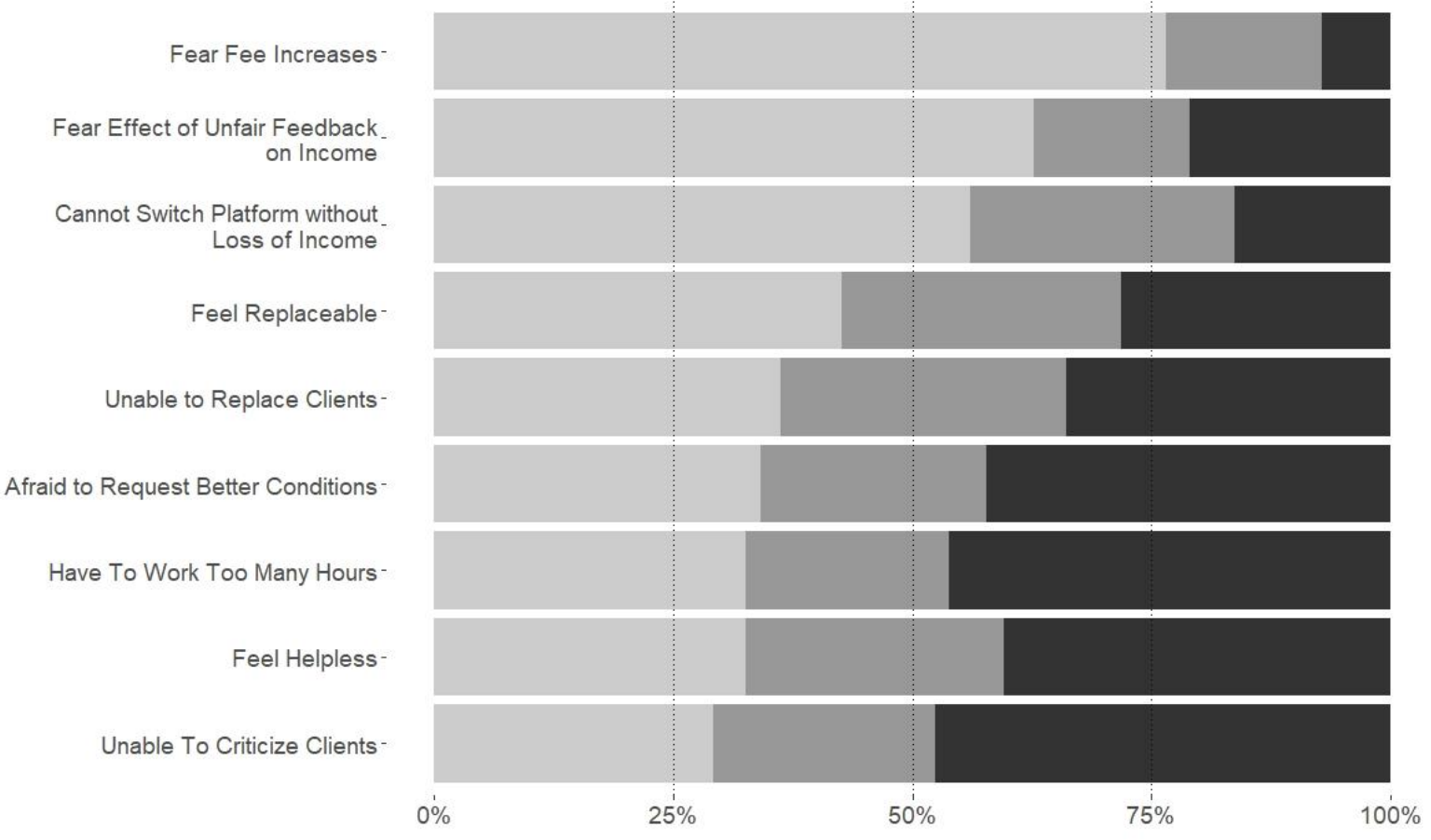

Finally, with regards to the Communication variable, survey respondents had little face-to-face communication with other workers, with $85 \%$ of workers never or rarely communicating in this way. However, as Figure 5 demonstrates, many workers were making use of digital technologies to communicate with each other on a regular basis, with $45 \%$ communicating through either social media or online forums at least once a week. In comparison, Southeast Asian and Sub-Saharan African platform workers working through similar platforms, surveyed by Wood et al. (2018), were slightly more likely to be in weekly contact with each other $(+13$ percentage points $(\mathrm{pp}))$. 
Figure 5: 'Communication' Independent Variable Underlying Items

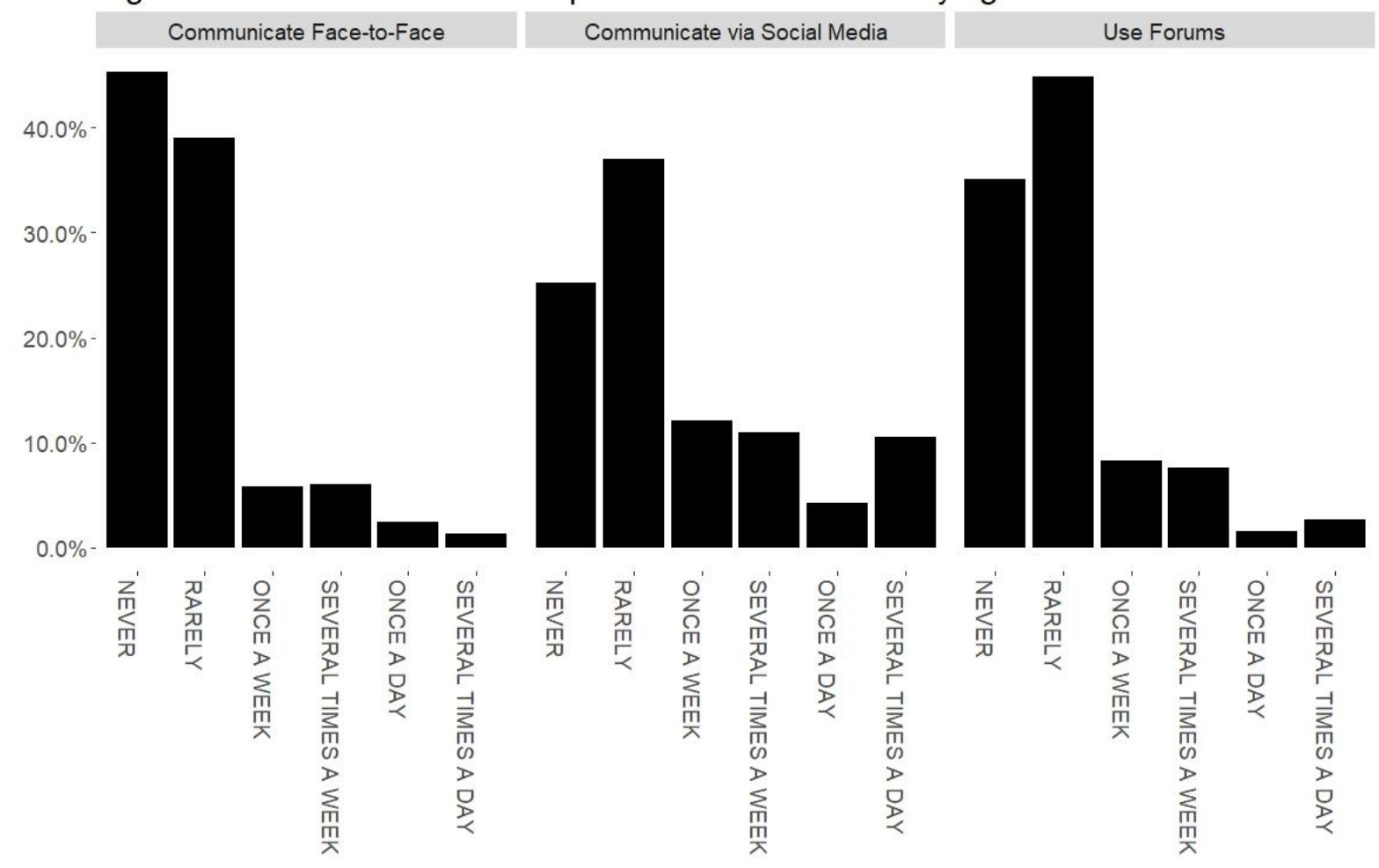

As for the items comprising our dependent variables, we find that $55 \%$ of workers

have taken some form of retaliatory action against individual clients: ending or threatening to end their contract or refusing to continue to work with them. Support for government regulation and minimum wages were also widespread, with $39 \%$ supporting the former and $55 \%$ the latter. Many of the workers we surveyed were also supportive of collective organisation. Fifty-nine per cent responded that they were interested in collaboratively improving wages. Fifty percent agreed or strongly agreed that if there were a trade union or workers' association for freelancers they would join.

It is interesting to compare the above with figures from standard workers. Kochan et al. (2019) find that $48 \%$ of non-union standard workers in the United States (US) would vote in favour of a union if given the opportunity and Pyman et al. (2009) find that $38.5 \%$ of nonunion Australian workers would be likely or very likely to join a union if they had the option 
to do so. In the UK between 40\% (Charlwood, 2002) and 46\% (Freeman and Bryson, 2006) of non-union workers would join a union if their colleagues formed one at their workplace. ${ }^{4}$ That support for unions among the surveyed platform workers here was similar to that found among standard workers in several high-income countries is perhaps surprising given the individualist attitudes that autonomous, self-employed workers have typically been found to hold (Evans, 1993; Jansen, 2011; 2019; Langsæther and Evans, 2020; Knutsen, 2018;

Svallfors, 2006; Van de Werfhorst and de Graaf, 2014).

The percentage of surveyed workers who support collaboratively improving wages (59\%) is slightly lower than the $71 \%$ figure obtained in a survey of similar African and Asian workers by Wood et al. (2018). As one would expect, far fewer workers were interested in organising a union themselves, with $9 \%$ agreeing or strongly agreeing. This is again lower than the 25\% figure for African and Asian workers (Wood et al. 2018). Lower support for collective organisation among European platform workers is surprising and will be returned to in the discussion.

\section{Using anger, dependence, and communication to explain protest}

To assess the influence of our three independent variables on workers' propensity to support and engage in different forms of protest, we estimate three OLS regressions, specifying the same model (1) for each of the three dependent variables: Individual Action, Collective Organisation, and State Regulation. Models include controls, $X_{k}$, for workers' age, sex, education level (whether possessing an undergraduate degree) ${ }^{5}$ country of residence, platform and length of time working on platforms. We standardise the constructed dependent and independent variables to facilitate the interpretation of results. ${ }^{6}$

$$
Y=\alpha+\beta_{1} \text { Anger }+\beta_{2} \text { Dependence }+\beta_{3} \text { Communication }+\sum_{k=4}^{n} \beta_{k} X_{k}+\varepsilon
$$


Results in Table 2 reveal that platform workers' feelings of anger are significantly associated with all three dependent variables: individual protest against clients (Individual Action), support for collective organisation (Collective Organisation), and support for the greater application of state regulations to platforms (State Regulation). The directions of the associations are consistent with the hypothesis that angrier workers are more likely to engage in or support protest. The association of anger with support for state regulation is particularly strong. A one standard deviation increase in worker anger is associated with a 0.4 standard deviation increase in support for greater application of state regulation to platforms. This means, for example, that a worker answering "Strongly Disagree" instead of "Disagree" on five of Anger's underlying items is associated with answering "Strongly Disagree" instead of "Disagree" on one of the items in State Regulation.

Communication with other platform workers is significantly associated with both Individual Action and Collective Organisation but not with State Regulation. Workers who are more frequently in contact with other workers on their platforms are more likely to engage in individual action against a client and to support Collective Organisation. The estimated associations are similar and moderate, implying a 0.2 standard deviation increase in individual action or support for Collective Organisation for every standard deviation increase in communication with other workers. Substantively, answering three categories more extreme on Communication (e.g. going from "Never" to "Several Times a Week") is associated with answering between a half and a whole category more extreme on both Individual Action and Collective Organisation.

Workers who are more dependent are more likely to support Collective Organisation but not Individual Action or State Regulation. The association is not particularly strong, however. A one standard deviation increase in Dependence is associated with a 0.1 standard deviation increase in support for Collective Organisation. Substantively, answering five 
categories more extreme on Dependence items is associated with answering half a category more extreme on Collective Organisation.

Results are not sensitive to which of the two platforms in the sample workers use. There is also little significant variation by country of residence (perhaps due to workers in the remote gig economy being normatively disembedded from social institutions, as argued by Wood et al. 2019b). The only significant differences being that workers in the UK are less likely to support Collective Organisation than those in the reference country, Finland. Workers in Romania are more likely to have taken individual action against clients. Age is only significantly associated with support for Collective Organisation, where support declines with age, suggesting younger platform workers are more supportive of collective organisation. Length of platform working experience is only associated, positively, with support for Individual Action, suggesting that as workers gain experience on their platform they increase in confidence in dealing robustly with clients. This may be due to workers building up a platform reputation which acts as a source of bargaining power as suggested by the qualitative research of Wood et al. (2019a) and Wood and Lehdonvirta (2021a). Gender is only significantly associated with support for State Regulation, where men are less likely to support regulation than women. Education levels are not associated with any of the dependent variables. The $\mathrm{R}^{2}$ values of the models are low, suggesting that a significant amount of variation in the dependent variables is either idiosyncratic or explained by unobserved variables. This is not unusual for research which seeks to explain complicated social phenomena such as attitudes towards protest.

Table 2 - Results of Multivariate Analyses 
State Individual Collective Regulation Action Action

\begin{tabular}{lccc} 
& $(1)$ & $(2)$ & $(3)$ \\
\hline Anger & $0.371^{* * *}$ & $0.181^{* * *}$ & $0.174^{* *}$ \\
& $(0.052)$ & $(0.053)$ & $(0.054)$ \\
Dependence & 0.086 & 0.070 & $0.134^{*}$ \\
& $(0.052)$ & $(0.053)$ & $(0.054)$ \\
Communication & -0.002 & $0.231^{* * *}$ & $0.211^{* * *}$ \\
& $(0.044)$ & $(0.045)$ & $(0.046)$ \\
Age & -0.0004 & 0.001 & $-0.013^{* *}$ \\
& $(0.005)$ & $(0.005)$ & $(0.005)$ \\
Male (Ref.: Female) & $-0.204^{*}$ & -0.136 & -0.014 \\
& $(0.087)$ & $(0.090)$ & $(0.091)$ \\
Graduate (Ref.: Non-Graduate) & 0.112 & 0.132 & -0.018 \\
& $(0.094)$ & $(0.096)$ & $(0.098)$ \\
Upwork (Ref.: PeoplePerHour) & -0.145 & -0.111 & -0.072 \\
& $(0.117)$ & $(0.120)$ & $(0.122)$ \\
Platform Work Experience & 0.001 & $0.153^{* * *}$ & 0.022 \\
& $(0.032)$ & $(0.033)$ & $(0.034)$
\end{tabular}

\section{Country (Ref.: Finland)}

\begin{tabular}{lccc} 
Germany & -0.060 & $0.327^{*}$ & -0.203 \\
& $(0.154)$ & $(0.158)$ & $(0.161)$ \\
Italy & 0.296 & -0.062 & -0.123 \\
& $(0.156)$ & $(0.160)$ & $(0.163)$ \\
Romania & 0.042 & $0.415^{* *}$ & -0.144 \\
& $(0.148)$ & $(0.152)$ & $(0.154)$ \\
Spain & 0.191 & 0.063 & 0.162 \\
& $(0.154)$ & $(0.158)$ & $(0.161)$ \\
United Kingdom & 0.049 & 0.248 & $-0.317^{*}$ \\
& $(0.153)$ & $(0.156)$ & $(0.159)$ \\
Constant & 0.069 & $-0.696^{* *}$ & $0.569^{*}$ \\
& $(0.240)$ & $(0.246)$ & $(0.250)$ \\
\hline Observations & 430 & 430 & 430 \\
$\mathrm{R}^{2}$ & 0.236 & 0.197 & 0.170 \\
Adjusted R & \\
Residual Std. Error $(\mathrm{df}=415)$ & 0.889 & 0.170 & 0.142 \\
F Statistic $(\mathrm{df}=14 ; 415)$ & $9.168^{* * *}$ & $7.287^{* * *}$ & $6.070^{* * *}$ \\
\hline Note $:$ & $* \mathrm{p}<0.05 ;{ }^{* *} \mathrm{p}<0.01{ }^{* * * *} \mathrm{p}<0.001$
\end{tabular}




\section{Discussion}

Qualitative research conducted in both the local gig economy (Cant, 2019; Cini and Goldmann, 2020; Lei, 2021; Tassinari and Maccarrone, 2020) and remote gig economy (Wood and Lehdonvirta, 2021a) has highlighted importance of the labour relationship for generating contentious politics. Our quantitative findings support the importance of antagonism inherent to the labour relationship in generating worker protest and support for collective action. Moreover, Wood and Lehdonvirta (2021a) argue that worker support for unions in the remote gig economy is generated from their position within relations of dependence, which limit the potential for individual responses to dissatisfaction with a platform, such as exiting the platform - a finding supported by our quantitative analysis. These findings also support Joyce's (2020) contention that platforms generate an unstable cash-nexus between workers and capital and that this can be a source of discontent. We find that these workers support unions because they feel anger over their treatment on platforms often having material grievances around platform rates and fees that impact their pay.

We also find that platform workers in the remote gig economy are more likely to support unions when solidarity develops as a result of digital communication with other workers. Previously, qualitative research in the local gig economy by Aslam and Woodcock (2019), Cant (2019), Cant and Woodcock (2020), Cini and Goldmann (2020), and Tassinari and Maccarrone (2020) has highlighted inter-worker communication as crucial for enabling protest. In the local gig economy, the importance of communication has been supported quantitatively by Maffie (2020) and Newlands et al. (2018) in their studies of ride hailing but this has not previously been quantitatively investigated in the remote gig economy. Therefore, an important contribution of our research is that it is the first to provide quantitative support for the role of communication in facilitating protest and support for trade unions among platform workers in the remote gig economy. 
A second important contribution of our study is that our findings also show that the importance of these factors (anger, dependency, and communication) varies significantly when we distinguish between different targets of protest and claim making in the remote gig economy. Concerning the state, the findings revealed that platform worker support for additional state regulation was significantly associated with worker anger but not with dependence on platforms or with communication between workers. When customers are the focus of protest, greater anger and communication between workers predict a greater propensity to refuse to work with particular clients and to cancel existing contracts, but greater dependence does not have such an effect. These findings highlight the importance of also adopting a relational approach to understanding protest, such as Kelly’s (1998) Mobilisation Theory.

Mobilisation Theory emphasises the role of individual subjective perceptions of injustice and the attribution of costs/benefits in predicting worker preference for different forms of collective action (Hodder et al., 2017). Support for state regulation carries relatively little risk for workers, so anger alone is enough to provoke it. But threatening customers or cancelling contracts risks current and future income, and therefore solidarity generated via communication appears important in providing workers with the resources - shared knowledge and moral support (i.e. social capital) - to convert anger into such risky action. Qualitative studies which have highlighted the importance of worker communication for dealing effectively with difficult customers lend additional support to this conclusion (Anwar and Graham, 2020a; 2020b; Wood et al., 2018; Wood and Lehdonvirta, 2021b). Even if workers are primarily engaging in online communities as means of personal expression and self-validation, in doing so they produce communal resources which act as public goods (Bennett and Segerberg, 2012) that strengthen worker bargaining power in relation to customers. 
Turning to collective forms of protest, previous research has highlighted that in the local gig economy support for unions among Uber drivers is associated with inter-worker communication (Maffie, 2020; Newlands et al. 2018). Likewise, results here reveal that communication is associated with support for collective organisation in the remote gig economy. However, support for collective organisation is also significantly associated with worker dependence. Mobilisation theory can again help us understand why, of the three targets for worker discontent that we have investigated, platform dependence only helps to explain support for collective organisation: collective organisation is likely especially beneficial to workers whose dependence undermines their individual bargaining power.

Our findings therefore highlight that, while injustice and anger are central to protest, solidarity and dependence are also important for explaining the dynamics of contention as they alter the perceived risks and benefits of particular remedies to injustice. Overall, the findings in this study highlight the value of Kelly's (1998) application of the contentious politics approach — developed by McAdam, Tarrow and Tilly (2001) — to understanding the 'new' social relations of digital technology and the future of work. This study additionally highlights that the issue of worker dependence is central to understanding collective mobilisation, trade union formation, and support for trade unions in the remote gig economy. Previous studies of protest in the local gig economy have explained divergent forms of collective mobilisation with reference to the influence of differing resources available to actors (e.g. Cini and Goldmann, 2020; Joyce et al., 2020). However, we have highlighted how platform worker support for these different strategies is, at least in the remote gig economy, also dependent on individual factors that shift the perceived costs and benefits of various responses to perceived injustices.

One limitation of our study is that our empirical material is limited to those platform workers providing remote digital services to clients, sometimes referred to as crowdworkers, 
remote gig workers, or online freelancers, and we are, therefore, unable to investigate industry differences. However, above, we highlighted that our review of existing research did not suggest the existence of industry patterns in terms of the selection of targets for collective action by platform workers despite the obvious spatial differences entailed by providing services locally to customers rather than remotely. Platform workers across different types of service provision have variously targeted action towards customers, platforms, and the state. In light of this claim-making heterogeneity and given the importance worker, customer, platform and state relations across the local/remote divide, we believe our findings may be applicable to platform workers beyond the remote gig economy. Nevertheless, the specific dynamics of contention may fluctuate for platform workers across the local/remote divide and across different sectors, in terms of the strength of the specific associations between the independent and dependent variables, due to differing perceived costs/benefits of action. Indeed, the union support figure in our survey is slightly higher $(+12 \mathrm{pp})$ than Vandaele et al. (2019) find among Belgian Deliveroo workers. This is surprising, as the geographic isolation and spatial barriers to communication entailed by this remote online gig work might be expected to make the emergence of collective solidaristic attitudes more difficult than in food delivery. However, the slightly lower figure of Vandaele et al. (2019) may be explained, as suggested by Barratt et al. (2020), by the lower perceived benefits vs. costs of unions for delivery workers due to the weak attachment of many delivery workers to platform work. In contrast workers in the remote gig economy tend to strongly identify with being freelancers and have a strong attachment to the work (Panteli et al., 2020; Soriano and Cabañes, 2020; Wood et al., 2018). Therefore, the application of our model and, in particular, the independent variables of anger, communication and dependency, to quantitative studies of contentious politics across the gig economy is an important avenue for future research. In 
fact, two of the authors are currently collecting data that would enable the generalisability of our findings to the local gig economy to be tested.

It should also be noted that the European workers in our study indicated lower levels of support for collective organisation than the Asian and African workers studied by Wood et al. (2018). This is surprising, since workers in the current study are located in countries with historically stronger and more institutionalised labour movements. Previous research has stressed that residence in an area with a tradition of unionisation is a strong predictor of union support among non-members (Charlwood, 2002). This surprising finding may be explained by lower levels of dependence and communication observed among these European platform workers compared to their Asian and African colleagues. Such an explanation underscores the importance of carefully considering the contribution of the differing social relations of the gig economy when explaining support for protest and contentious activity.

\section{Policy implications}

The findings presented in this article suggest that unions are unlikely to have majority appeal for remote workers in the gig economy unless greater numbers of these workers find themselves in a position of dependence, a situation that is a possible consequence of the current coronavirus crisis. We have also argued that this might also hold true for workers in the local gig economy and may even be amplified in sectors, such as food delivery, where many workers have a weak attachment to the work - as argued by Barratt et al. (2020). For instance, in the UK, a number of studies have sought to undertake representative surveys of the gig economy and, while the exact estimates for this hard-to-reach population are uncertain, only a minority of workers have been found to earn the majority of their income from the gig economy. Estimates of such workers range from 14\% (Lepanjuuri et al., 2018) 
to $36 \%$ (Pesole et al., 2017) in the UK. However, in the UK, statutory union recognition requires evidence that a majority of workers within a proposed bargaining unit are in favour of recognition. Our findings therefore support the assertion of Tassinari and Maccarrone (2020: 38 ) that different levels of dependence may act as a barrier to the 'consolidation of shared identities' among platform workers and are in line with the findings of Barratt et al. (2020) that the weak attachment of many food delivery workers reduces the propensity for collective action. Therefore, in the UK a more viable strategy for the minority of workers who are willing to join or even set up a union would be that they form the core of a workers' organisation that campaigns for state regulation and the voluntary recognition of a union, rather than seeking statutory union recognition and collective bargaining (in the UK Uber drivers seem to have some success following such a strategy). Our findings suggest that such efforts are likely to be widely supported by workers including those who are less favourably disposed towards collective organisation due to lower levels of platform dependence or less communication with other workers.

Our findings have also provided further evidence for the importance of digital communication (forums, social media, mobile telephony) in empowering remote workers to stand up to individual abuse by clients. Digital communication acts as a source of social capital for platform workers and helps to foster a sense of collective solidarity. A second implication for policy is therefore that the extension of such networks could improve platform worker bargaining power in relation to customers in some sectors of the gig economy. 


\section{Conclusion}

This article has made two main contributions to theoretical debates on platform worker protest. First, a novel empirical setting has been used to provide a robust defence of the application of sociological theory to the 'new' social relations of the gig economy. In particular, both structured antagonism and solidarity in the labour process (Atzeni, 2009; 2010; Edwards, 1986) and a dynamic relational understanding of the mobilisation process (Kelly, 1998; McAdam et al., 2001) are important for explaining worker support for different action (see also the qualitative local gig economy research of Cini and Goldmann (2020)).

Second, by providing an individual level, micro-mobilisation account we elaborate on existing research that seeks to explain the heterogeneity of platform worker action through resource mobilisation and organisational actors (e.g. Cini and Goldmann (2020); Joyce et al., 2020). Vallas and Schor (2020) argue that extant gig economy literature has been plagued by the theoretical presentation of workers as a homogenous group. In contrast, we demonstrate the importance of individual circumstances in explaining worker support for different remedies to perceived injustices. In particular, we have highlighted the varying importance of anger generated from antagonism, dependence on specific platforms, and solidarity generated through communication with other workers in explaining the targets of platform worker protest. Overall, our findings have substantive value in extending our understanding of the new world of platform-mediated gig work, which is growing rapidly (Kässi and Lehdonvirta, 2016) by providing the first quantitative investigation of the dynamics of contention in the remote gig economy. In particular, we have revealed surprisingly high levels of discontent, support for state regulation, and support for collective organisation among self-employed freelancers. 
Notes

1. Charles Tilly also applied this approach to work himself in Tilly and Tilly (1999)

2. Factor analysis to construct the dependent and independent variables was also carried out. This approach produced an identical pattern of regression results to those in Table 2. For ease of presentation and interpretation we present only the results from summed Likert items.

3. Analyses were also conducted using an eleven-item Dependence measure which additionally included the percentage of monthly income earned from the platform and the number of hours worked on the platform in the previous week. These items were measured using different response scales than the other items in the Dependence variable (i.e. not Strongly Disagree to Strongly Agree). The inclusion of these items did not affect the significance or direction of the results. For parsimony we chose not to include them in the main results presented here.

4. While support for unions in the UK is similar to Germany, support for unions is, however, significantly higher among employees (at least 10 percentage points) in Italy, Spain and Finland (no data on union support in Romania is readily available) (D’Art and Turner, 2008).

5. Results are robust to alternative operationalizations of education level: a set of n-1 dummies for the $\mathrm{n}=9$ education categories recorded (from no schooling to doctorate) or an integer score (0-8) for these categories.

6. Neither the significance nor direction of the estimated associations is affected by this.

\section{References}

Ackroyd, S. and Thompson, P. (1999) Organizational Misbehaviour, London, Sage. 
Anwar, M.A. and M. Graham (2020a) Hidden transcripts of the gig economy: Labour agency and the new art of resistance among African gig workers. Environment and Planning A: Economy and Space 52(7): 1269-1291.

Anwar, M. A. and M. Graham. (2020b). Between a Rock and a Hard Place: Freedom, Flexibility, Precarity and Vulnerability in the Gig Economy in Africa. Competition and Change. 25 (2): 237-258

Aslam, Y. and Woodcock, J. (2020). A History of Uber Organizing in the UK. South Atlantic Quarterly, 119(2). 412-421

Atzeni, M. (2009). 'Searching for Injustice and Finding Solidarity? A Contribution to the Mobilisation Theory Debate', Industrial Relations Journal, 40(1), 5-16.

Atzeni, M. (2010). Workplace Conflict: Mobilisation and Solidarity in Argentina. London: Palgrave Macmillan.

Atzeni, M. (2016) Beyond trade unions' strategy? The social construction of precarious workers organizing in the city of Buenos Aires. Labor History 57(2): 193-214.

Barratt, T., Good, C. and Veen, A. (2020) 'I'm my own boss. . .': Active intermediation and 'entrepreneurial' worker agency in the Australian gig-economy. Environment and Planning A: Economy and Space 52(8): 1643-1661.

Bennett, L.W. and Segerberg, A. (2012). The Logic of Connective Action. Information, Communication \& Society, 15:5, 739-768

Bryson, A. and Freeman, R. (2006) What Voice Do British Workers Want? CEP Discission Paper No 731. London: Centre for Economic Performance, London School of Economics and Political Science

Cant, C. (2019) Riding for Deliveroo: Resistance in the New Economy, Cambridge, Polity. 
Cant, C. and Woodcock, J. (2020). Fast Food Shutdown: From disorganisation to action in the service sector. Capital \& Class.

Charlwood, A. (2002). Why do Non-union employees want to unionize? evidence from Britain. British Journal of Industrial Relations, 40(3), 463-491.

Chen, J.Y. (2018). Thrown under the bus and outrunning it! The logic of Didi and taxi drivers' labour and activism in the on-demand economy: New Media \& Society 20(8): 2691-2711.

Cini, L. and Goldmann, B. (2020) The Worker Capabilities Approach: Insights from Worker Mobilizations in Italian Logistics and Food Delivery. Work, Employment and Society Epub ahead of print.

D'Art, D. and Turner, T. (2008) Workers and the Demand for Trade Unions in Europe: Still a Relevant Social Force? Economic and Industrial Democracy 29:2 165-191

Dunlop, J. (1958) Industrial relations systems, New York, NY, Holt.

Dunn, M. (2020). "Making gigs work: digital platforms, job quality and worker motivations." New Technology, Work and Employment Epub ahead of print.

Edwards, P.K. (1986) Conflict at Work: A Materialist Analysis of Workplace Relations: Oxford, Basil Blackwell.

Evans, D. (2003) Some Empirical Aspects of Multi-sided Platform Industries. Review of Network Economics 2 191-209.

Evans, G. (1993). The Decline of Class Divisions in Britain? Class and Ideological Preferences in the 1960s and the 1980s. British Journal of Sociology. 449-471. https://doi.org/10.2307/591812 
Gandini, A. (2019) Labour process theory and the gig economy. Human Relations, 72, 10391056.

Goods, C., Veen, A., Barratt T. (2019). 'Is your gig any good?' Analysing job quality in the Australian platform-based food-delivery sector. Journal of Industrial Relations 61(4): $502-527$.

Heckscher, C. and McCarthy, J. (2014). Transient Solidarities: Commitment and Collective Action in Post-Industrial Societies. British Journal of Industrial Relations, 52(4), 627657.

Hodder, A., Williams, M., Kelly, J. and McCarthy, N. (2017). Does Strike Action Stimulate Trade Union Membership Growth?. British Journal of Industrial Relations, 55(1), 165-186.

Howcroft, D. and Bergvall-Kåreborn, B. (2019) A Typology of Crowdwork Platforms. Work, Employment and Society 33, 21-38.

Huws, U., N.H. Spencer and S. Joyce (2016), Crowd Work in Europe Preliminary Results From a Survey in the U.K., Sweden, Germany, Austria and the Netherlands (Brussels: Foundation for European Progressive Studies).

Irani, L. and Silberman, M.S. (2013) 'Turkopticon: Interrupting Worker Invisibility in Amazon Mechanical Turk', Proceedings of the ACM Conference on Human Factors in Computing Systems (CHI), Paris, France.

Jansen, G. (2011). Social cleavages and political choices: Large-scale comparisons of social class, religion and voting behaviour in Western Democracies. Nijmegen, the Netherlands: Ipskamp Drukkers BV. 
Jansen, G. (2019). Self-employment as atypical or autonomous work: Diverging effects on political orientations. Socio Economic Review, 17(2), 381-407.

Jarley, P. (2005) Unions as Social Capital: Renewal through a Return to the Logic of Mutual Aid? Labor Studies Journal 29(4): 1-26.

Johnston, H. and Land-Kazlauskas, C. (2018). Organizing on-demand: Representation, voice, and collective bargaining in the gig economy. Conditions of Work and Employment Series, 94. Geneve: ILO.

Josserand, E., and Kaine, S. (2019). Different directions or the same route? The varied identities of ride-share drivers. Journal of Industrial Relations 61(4):549-573.

Joyce, S. (2020). Rediscovering the cash nexus, again: Subsumption and the labour-capital relation in platform work. Capital and Class 44(4): 541-552.

Joyce, S., Neumann, D., Trappmann, V. and Umney, C. (2020). A Global Struggle: Worker Protest in the Platform Economy. ETUI Research Paper - Policy Brief 2/2020, http://dx.doi.org/10.2139/ssrn.3540104

Kässi, O. and Lehdonvirta, V. (2018) 'Online labour index: Measuring the online gig economy for policy and research', Technological Forecasting and Social Change, $137,241-248$.

Kellogg, K.C., Valentine, M. Christin A (2020). Algorithms at Work: The New Contested Terrain of Control. Academy of Management Annals, 14, 366-410.

Kelly, J. (1998) Rethinking Industrial Relations: Mobilisation, Collectivism and Long Waves. London, Routledge. 
Kochan, T.A., Yang, D., Kimball, W.T., Kelly, E.L. Worker voice in America: Is there a gap between what workers expect and what they experience? Industrial and Labor Relations Review, 71 (1): 3-38.

Knutsen, O. (2018). Social structure, value orientations and party choice in Western Europe. Palgrave Studies in European Political Sociology. Cham, Switzerland: Palgrave Macmillan.

Langsæther, P.E. and Evans, G. (2020). More than self-interest: Why different classes have different attitudes to income inequality. British Journal of Sociology, 71(2),

Lehdonvirta, V. (2016) 'Algorithms That Divide and Unite: Delocalisation, Identity and Collective Action in 'Microwork'.' In Flecker J (ed) Space, Place and Global Digital Work: Dynamics of Virtual Work. London, Palgrave Macmillan 53-80.

Lehdonvirta, V., Kässi, O., Hjorth, I., Bernard, H. and Graham, M. (2019) 'The global platform economy: A new offshoring institution enabling emerging-economy microproviders', Journal of Management, 45, 567-599.

Lei Ya-Wen. 2021. "Delivering Solidarity: Platform Architecture and Collective Contention in China's Platform Economy." American Sociological Review EPub ahead of Print https://doi.org/10.1177/0003122420979980.

Lepanjuuri, K., Wishart, R., and Cornick, P. (2018). The Characteristics of Those in the Gig Economy: Final Report. London: BEIS.

Maffie M.D., (2020), The Role of Digital Communities in Organizing Gig Workers. Industrial Relations: A Journal of Economy and Society (59):1: 123-149.

McAdam, D. (1988). Micromobilisation Contexts and Recruitment to Activism. International Social Movement Research 1: 125-154. 
McAdam, D. Tarrow, S. and Tilly, C. (2001). Dynamics of Contention. New York: Cambridge University Press.

Möhlmann, M. and Zalmanson, L. (2017) Hands on the Wheel: Navigating Algorithmic Management and Uber Drivers' Autonomy. In Proceedings of the International Conference on Information Systems (ICIS), December 10-13 Seoul, South Korea (pp.1-17).

Morgan, G. and Pulignano, V. (2019). Solidarity at Work: Concepts, Levels and Challenges. Work, Employment and Society, 34(1): 18-34.

Newlands, G., Lutz, C. and Fieseler, C. (2018) 'Collective action and provider classification in the sharing economy', New Technology, Work and Employment, 33, 250-267.

Panteli, N., Rapti A. and Scholarios D. (2020) 'If He Just Knew Who We Were': Microworkers' Emerging Bonds of Attachment in a Fragmented Employment Relationship. Work, Employment and Society, Epub ahead of print https://doi.org/10.1177/0950017019897872

Pesole, A., Urzí Brancati, M.C., Fernández-Macías, E., Biagi, F. and González Vázquez, I. (2018) Platform Workers in Europe, JRC Science for Policy Report, Brussels, European Commission.

Putnam, R.D. (2000) Bowling Alone: The Collapse and Revival of American Community. New York City: Simon \& Schuster.

Pyman, A., Teicher, J., Cooper, B., Holland, P. (2009). Unmet demand for union membership in Australia. Journal of Industrial Relations 51 (1), 5-24.

Ravenelle, A. (2019). Hustle and gig: Struggling and surviving in the sharing economy. Berkeley: University of California Press. 
Saundry R., Stuart M., and Antcliff V. (2012) Social Capital and Union Revitalization: A Study of Worker Networks in the UK Audio-Visual Industries. British Journal of Industrial Relations 50(2): 263-286.

Schor JB., Attwood-Charles. W., Cansoy, M., Legdegaard, I., and Wengronowitz, R., (2020) Dependence and precarity in the platform economy. Theory and Society 49:833-861.

Snow, D.A., Rochford Jr, E.B, Worden, S.K., Benford R.D. (1986) Frame alignment processes, micromobilization, and movement participation. American sociological review, 464-481.

Svallfors, S. (2006). The Moral Economy Of Class: Class And Attitudes In Comparative Perspective. Stanford, California: Stanford University Press.

Tassinari, A. and Maccarrone, V. (2020) 'Riders on the Storm: Workplace Solidarity among Gig Economy Couriers in Italy and the UK', Work, Employment and Society, 34, 3554.

Tilly, C. (1978). From Mobilisation to Revolution. Reading, MA: Addison-Wesley.

Tilly, C. and Tilly, C. (1998). Work Under Capitalism. Boulder, Colorado: Westview Press. Vallas, S. and Schor, J.P. (2020) What do Platforms do? Understanding the Gig Economy. Annual Review of Sociology 46(16): 1-22.

Vandaele, K., Piasna, A. and Drahokoupil, J. (2019). 'Algorithm Breakers' Are not a Different 'Species': Attitudes Towards Trade Unions of Deliveroo Riders in Belgium. ETUI Research Paper -Working Paper 2019.06. http://dx.doi.org/10.2139/ssrn.3402899 
Van de Werfhorst H.G. and de Graaf ND (2004) The sources of political orientations in postindustrial society: social class and education revisited. British Journal of Sociology 55(2): 211-235

Wood, A.J. (2015). Networks of Injustice and Worker Mobilisation at Walmart. Industrial Relations Journal 46(4): 259-274.

Wood, A.J, (2020). Despotism on Demand: How Power Operates in the Flexible Workplace. Ithaca (NY): Cornell University Press.

Wood, A.J., Graham, M., Lehdonvirta, V. and Hjorth, I. (2019a) 'Good gig, bad gig: autonomy and algorithmic control in the global gig economy', Work, Employment and Society, 33, 56-75.

Wood, A.J., Graham, M., Lehdonvirta, V, and Hjorth, I (2019b) 'Networked but Commodified: The (Dis)Embeddedness of Digital Labour in the Gig Economy', Sociology, 53, 931-950.

Wood, A. J., Lehdonvirta, V. and Graham, M. (2018) 'Workers of the Internet unite? Online freelancer organisation in six Asian and African countries', New Technology, Work and Employment, 33, 95-112.

Wood, A.J. and Lehdonvirta, V. (2021a). Antagonism beyond employment: how the 'subordinated agency' of labour platforms generates conflict in the remote gig economy. Socio-Economic Review Epub ahead of print

\section{https://osf.io/preprints/socarxiv/y943w/}

Wood, A.J. and Lehdonvirta, V. (2021b). Platform Precarity: surviving algorithmic insecurity in the gig economy. Working paper for the 'AI at Work: Automation, Algorithmic 
Management, and Employment Law' Online Workshop at the University of Sheffield, $31^{\text {st }}$ March 2021. http://dx.doi.org/10.2139/ssrn.3795375

Tables

Table 1: Existing Research on Protest in the Gig Economy

\begin{tabular}{|c|c|c|c|c|}
\hline $\begin{array}{l}\text { Target of } \\
\text { Protest }\end{array}$ & Platform & Industry & Action & Citation \\
\hline \multirow[t]{8}{*}{ Customer } & MTurk & Digital & Client rating plugin & $\begin{array}{l}\text { Irani \& Silberman } \\
(2013)\end{array}$ \\
\hline & $\begin{array}{l}\text { Freelance } \\
\text { Platform }\end{array}$ & Digital & Price norms & Wood et al. (2018) \\
\hline & $\begin{array}{l}\text { Freelance } \\
\text { platform }\end{array}$ & Digital & $\begin{array}{l}\text { Publicly shame bad } \\
\text { clients }\end{array}$ & $\begin{array}{l}\text { Anwar and Graham, } \\
\text { (2020a); Wood et al., } \\
(2018)\end{array}$ \\
\hline & $\begin{array}{l}\text { Freelance } \\
\text { platform }\end{array}$ & Digital & $\begin{array}{l}\text { Threats to end } \\
\text { contract }\end{array}$ & $\begin{array}{l}\text { Wood and } \\
\text { Lehdonvirta (2021a) }\end{array}$ \\
\hline & $\begin{array}{l}\text { Freelance } \\
\text { platform }\end{array}$ & Digital & $\begin{array}{l}\text { Withhold work from } \\
\text { clients }\end{array}$ & $\begin{array}{l}\text { Anwar and Graham, } \\
\text { (2020a) }\end{array}$ \\
\hline & $\begin{array}{l}\text { Freelance } \\
\text { platform }\end{array}$ & Digital & $\begin{array}{l}\text { Circumvent client } \\
\text { monitoring of work }\end{array}$ & $\begin{array}{l}\text { Anwar and Graham, } \\
\text { (2020a); Wood et al., } \\
(2019 a)\end{array}$ \\
\hline & Uber & Driving & $\begin{array}{l}\text { Cancelling rides to } \\
\text { avoid bad } \\
\text { customers/ratings. }\end{array}$ & $\begin{array}{l}\text { Möhlmann and } \\
\text { Zalmanson (2017) }\end{array}$ \\
\hline & UberEats & Delivery & $\begin{array}{l}\text { Protests outside } \\
\text { restaurants for } \\
\text { reduced waiting times }\end{array}$ & $\begin{array}{l}\text { Cant \& Woodcock } \\
(2020)\end{array}$ \\
\hline \multirow[t]{7}{*}{ Platform } & MTurk & Digital & $\begin{array}{l}\text { Petition and email } \\
\text { campaign }\end{array}$ & Lehdonvirta (2016) \\
\hline & $\begin{array}{l}\text { Freelance } \\
\text { Platform } \\
\end{array}$ & Digital & $\begin{array}{l}\text { Petition and forum } \\
\text { campaign }\end{array}$ & $\begin{array}{l}\text { Wood \& Lehdonvirta } \\
(2019)\end{array}$ \\
\hline & Deliveroo & Delivery & $\begin{array}{l}\text { Strikes and } \\
\text { demonstrations }\end{array}$ & $\begin{array}{l}\text { Cant (2019); } \\
\text { Tassinari and } \\
\text { Maccarrone (2020); } \\
\text { Cini and Goldmann } \\
(2020)\end{array}$ \\
\hline & Foodora & Delivery & $\begin{array}{l}\text { Strikes and } \\
\text { demonstrations }\end{array}$ & $\begin{array}{l}\text { Tassinari and } \\
\text { Maccarrone (2020) }\end{array}$ \\
\hline & UberEats & Delivery & $\begin{array}{l}\text { Strikes and } \\
\text { demonstrations }\end{array}$ & $\begin{array}{l}\text { Cant \& Woodcock } \\
(2020)\end{array}$ \\
\hline & Uber & Driving & $\begin{array}{l}\text { Strikes and } \\
\text { demonstrations }\end{array}$ & $\begin{array}{l}\text { Aslam \& Woodcook } \\
\text { (2019) }\end{array}$ \\
\hline & Meituan & Delivery & $\begin{array}{l}\text { Strikes and } \\
\text { demonstrations }\end{array}$ & Lei (2021) \\
\hline
\end{tabular}




\begin{tabular}{|l|l|l|l|l|}
\hline & Ele.me & Delivery & $\begin{array}{l}\text { Strikes and } \\
\text { demonstrations }\end{array}$ & Lei (2021) \\
\hline & Didi & Driving & App Bots & Chen (2018) \\
\hline State & Uber & Driving & $\begin{array}{l}\text { Demonstrations; } \\
\text { legal action; legal } \\
\text { enactment }\end{array}$ & $\begin{array}{l}\text { Aslam \& Woodcook } \\
\text { (2019); Johnston and } \\
\text { Land-Kazlauskas } \\
(2019)\end{array}$ \\
\hline & Crowdflower & Digital & Legal action & Lehdonvirta (2016) \\
\hline
\end{tabular}

Table 2 - Results of Multivariate Analyses

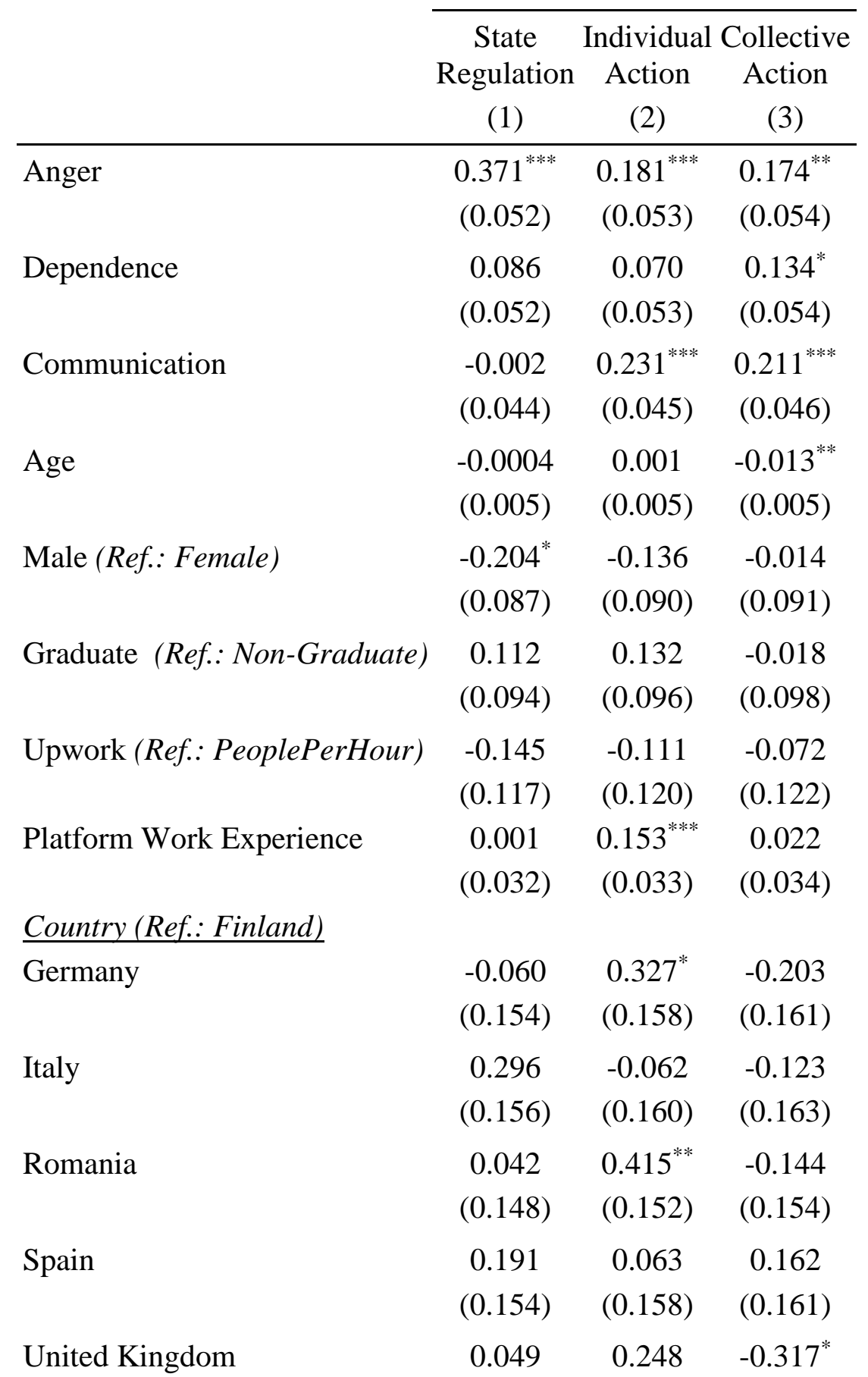




\begin{tabular}{|c|c|c|c|}
\hline \multirow{3}{*}{ Constant } & $(0.153)$ & $(0.156)$ & $(0.159)$ \\
\hline & 0.069 & $-0.696^{* *}$ & $0.569^{*}$ \\
\hline & $(0.240)$ & $(0.246)$ & $(0.250)$ \\
\hline Observations & 430 & 430 & 430 \\
\hline $\mathrm{R}^{2}$ & 0.236 & 0.197 & 0.170 \\
\hline Adjusted $\mathrm{R}^{2}$ & 0.210 & 0.170 & 0.142 \\
\hline Residual Std. Error $(\mathrm{df}=415)$ & 0.889 & 0.911 & 0.926 \\
\hline F Statistic $(\mathrm{df}=14 ; 415)$ & $9.168^{* * *}$ & $7.287^{* * *}$ & $6.070^{* * *}$ \\
\hline
\end{tabular}

\section{Figures}

Figure 1: Sex and Age Group of Respondents

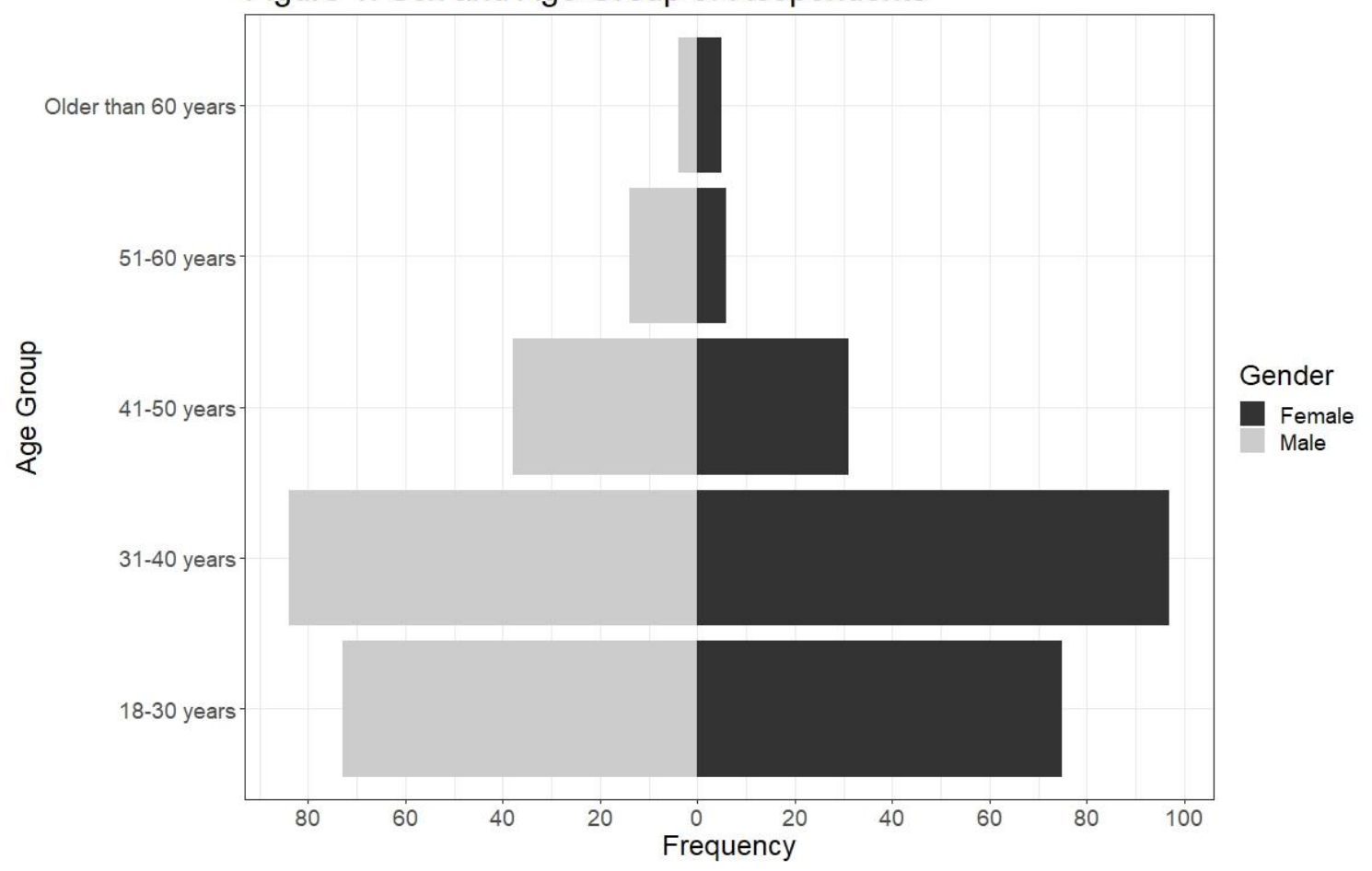


Figure 2: What is the highest level of education you have completed?

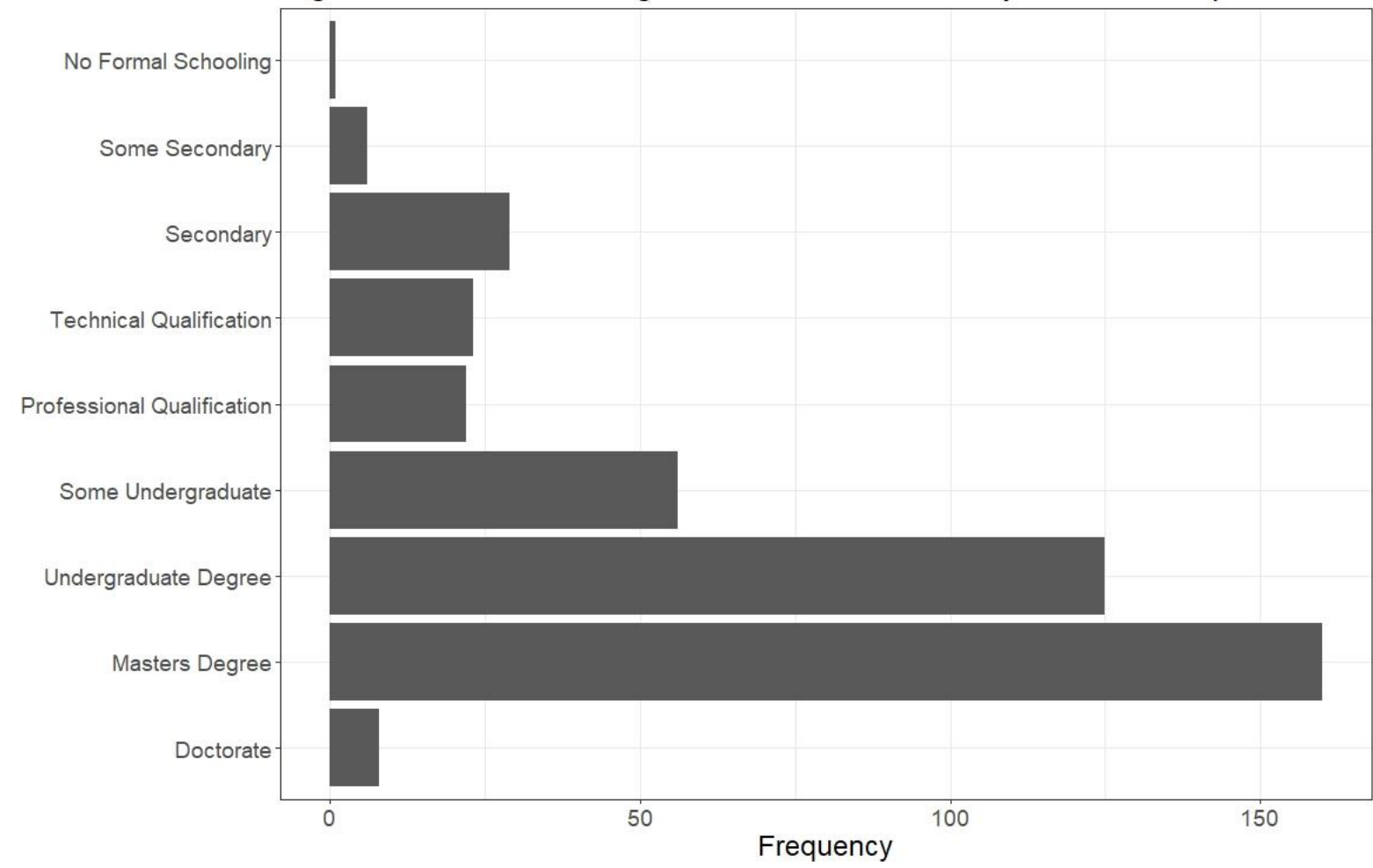

Figure 3: 'Anger' Independent Variable Underlying Items

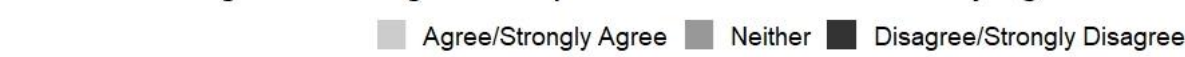

Fees Too High -

Rates Too Low ${ }^{-}$

Rates Lower Than Deserved-

Limit Foreign Competition-

Platforms Benefit Shareholders at Expense of Worker

Supported by Platform -

Platforms Too Powerful-

Treated Unfairly-

Late Pay-

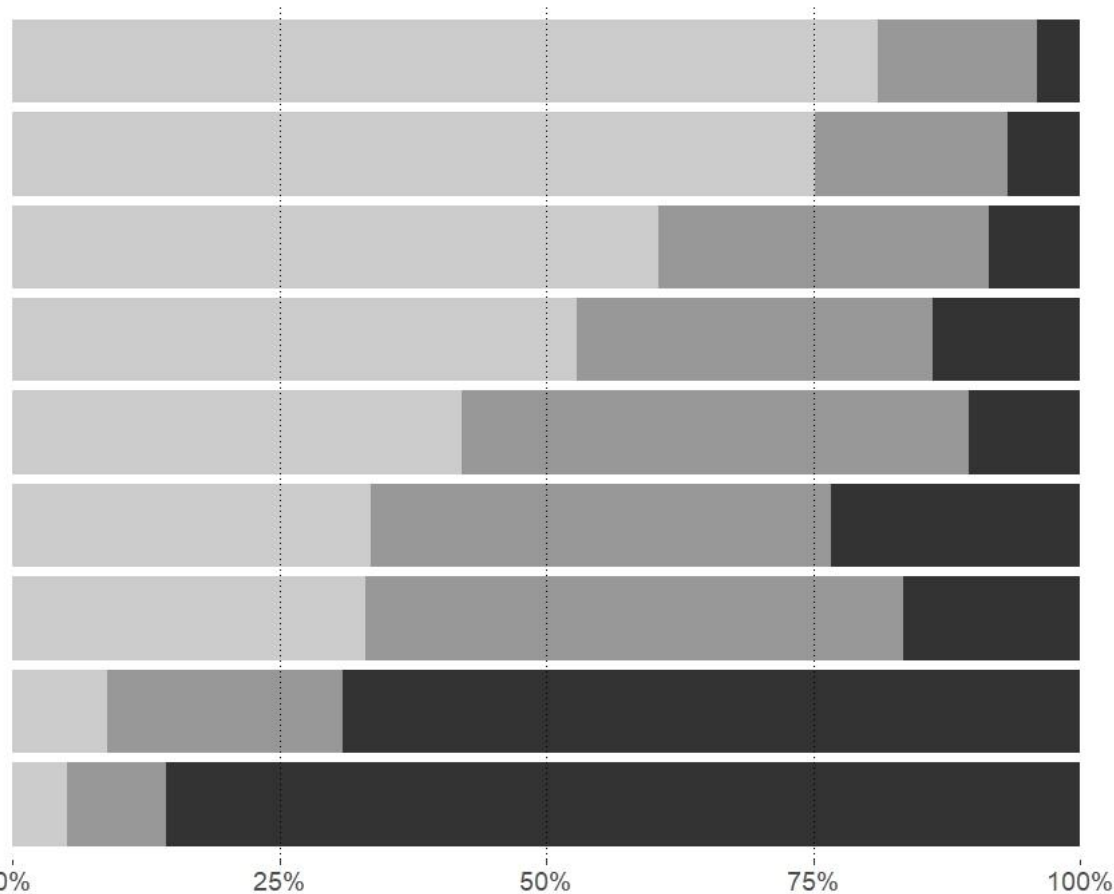


Figure 4: 'Dependence' Independent Variable Underlying Items Agree/Strongly Agree $\square$ Neither Disagree/Strongly Disagree

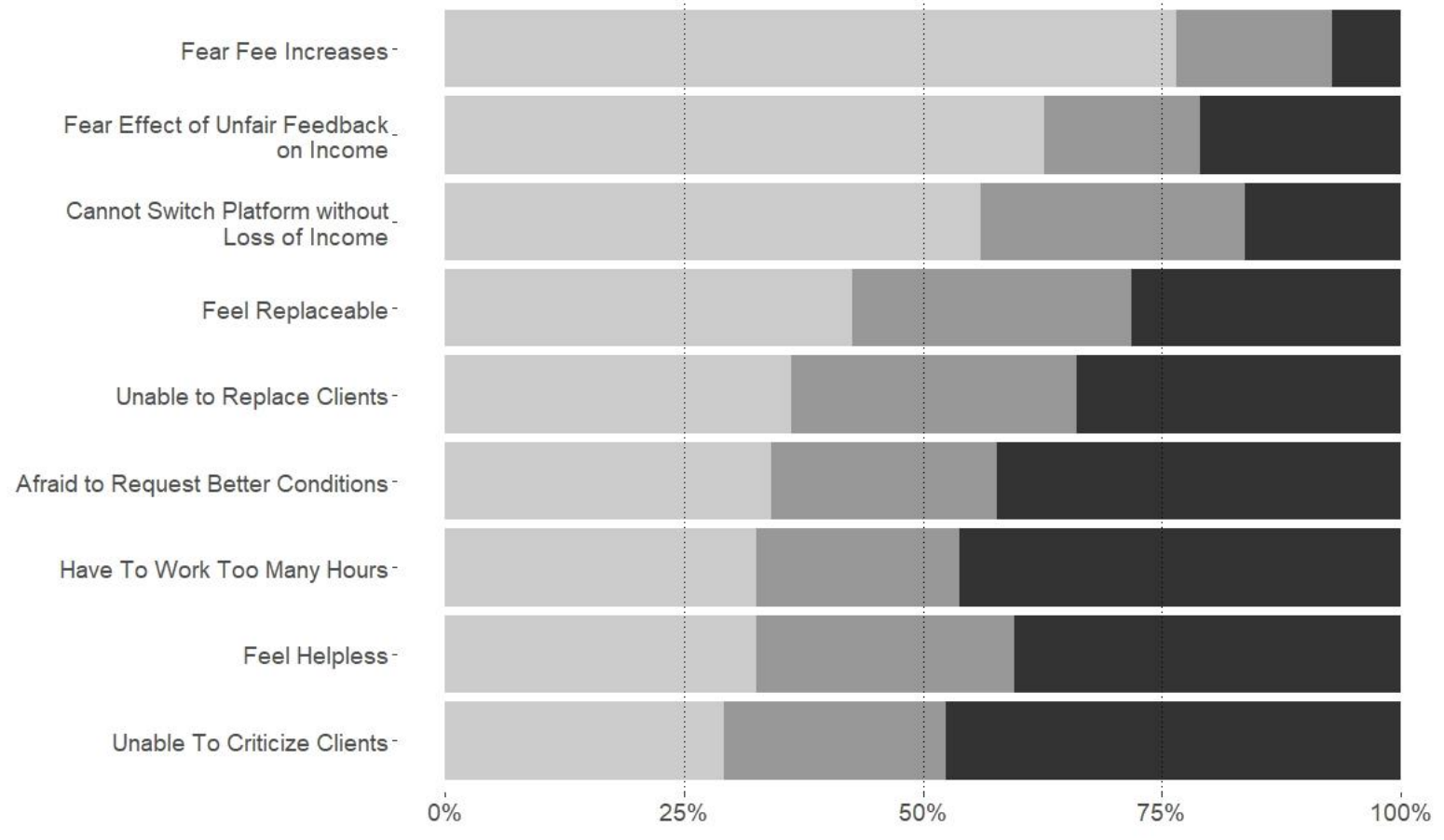

Figure 5: 'Communication' Independent Variable Underlying Items

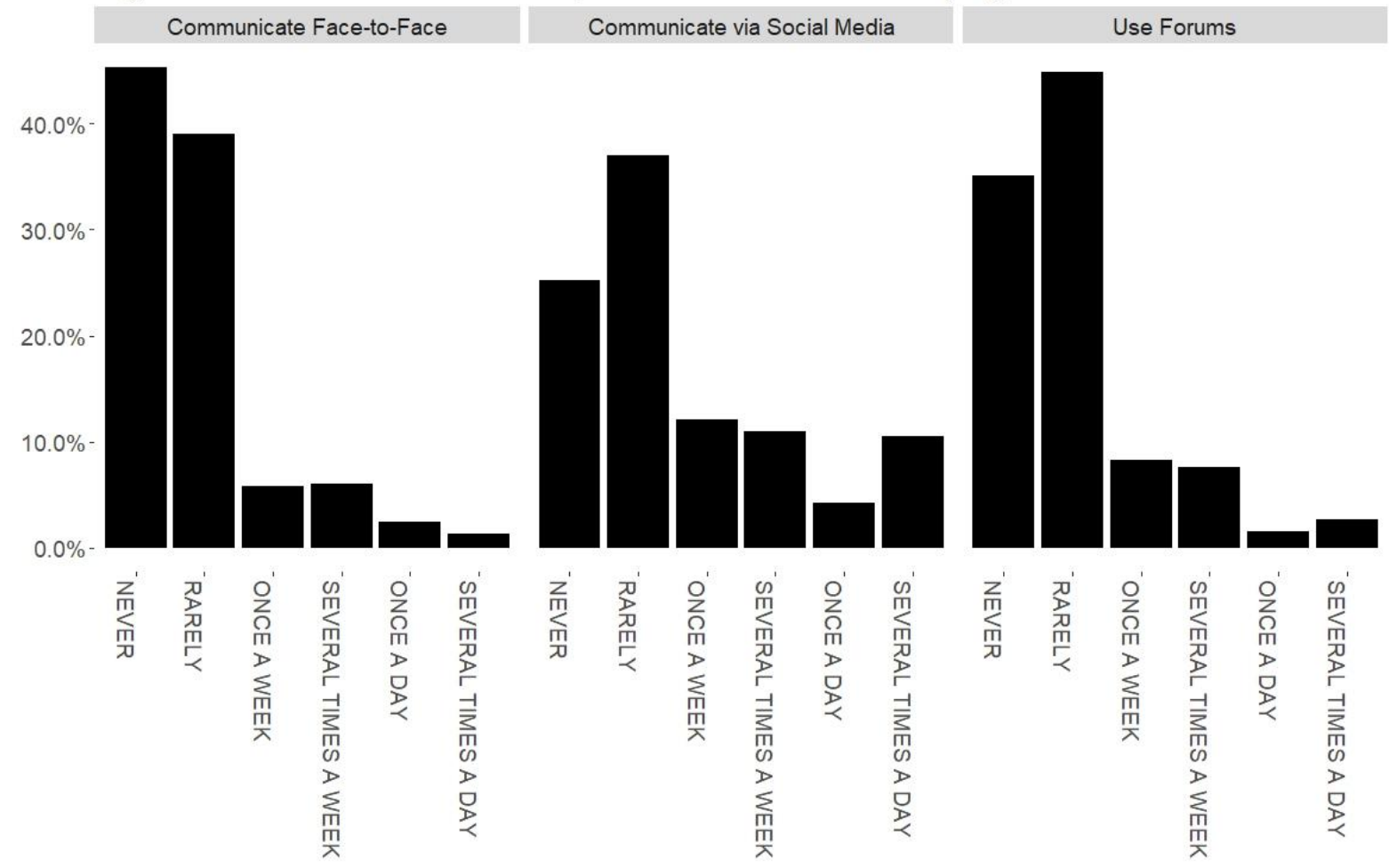

